\title{
Meningkatan Keterampilan Proses Sains melalui Metode Pembelajaran Eksperimen
}

\author{
Kamila Mahabatillah* \\ Prodi Pendidikan Guru PAUD, Fakultas Tarbiyah dan Keguruan, \\ Universitas Islam Bandung, Indonesia. \\ *kamilamahabatillah148@gmail.com
}

\begin{abstract}
The problem in this study has not been seen in children's science process skills. The teacher applies a learning process that is based on student worksheets and the learning process is still teachercentered. This causes children to be bored and have difficulty in obtaining new information, resulting in children's scientific process skills not developing properly. The purpose of this study was to determine: (1) Description of children's science process skills before applying the experimental learning method to the introduction of natural phenomena (2) Description of the implementation of natural symptom recognition activities through experimental learning methods in improving children's science process skills (3) Finding the results of science process abilities after applying the experimental learning method to the introduction of natural phenomena, (4) Identifying the effect of the experimental learning method in increasing children's science process skills. This study uses a quantitative research type of quasi-experimental research. The measurement of this study uses a rating scale while in testing the truth of the hypothesis using theformula, the Independent $\mathrm{T}$ Test value of sig. (2-tailed) of $0.001<0.05$, Ho rejected and Ha accepted. In accordance with the criteria for testing the hypothesis, namely sig. (2-tailed) $<0.05$ so it can be stated that there is a significant difference in results between the experimental class and the control class on science process skills in recognizing rain natural phenomena
\end{abstract}

Keywords: science process skills, experimental learning methods, natural phenomena.

Abstrak. Permasalahan dalam penelitian ini belum terlihatnya keterampilan proses sains anak. Guru menerapkan proses pembalajaran yang terpacu pada lembar kerja siswa serta dalam proses pembelarajan masih berpusat pada guru. Hal ini menyebabkan anak bosan dan kesulitan anak dalam memperolah informasi baru, mengakibatkan keterampilan proses sains anak belum berkembang dengan baik. Tujuan penelitian ini untuk mengetahui : (1) Gambaran keterampilan proses sains anak sebelum diterapkan metode pembelajaran eksperimen pada pengenalan gejala alam (2) Gambaran pelaksanan kegiatan pengenalan gejala alam melalui metode pembelajaran eksperimen dalam meningkatkan keterampilan proses sains anak (3) Menemukan hasil kemampuan proses sains anak sesudah diterapkan metode pembelajaran eksperimen pada pengenalan gejala alam, (4) Mengidentifikasi pengaruh metode pembelajaran eksperimen dalam meningkat keterampilan proses sains anak. Penelitian ini menggunakan penelitian kuantitatif jenis penelitian quasi eksperimen. Pengukuran penelitian ini menggunakan rating scale adapun dalam menguji kebenaran dari hipotesis menggunakan rumus Uji Independent T nilai sig. (2-tailed) sebesar 0,001 <0,05, maka Ho ditolak dan Ha diterima. Sesuai dengan kriteria uji hipotesis yaitu sig. (2-tailed) $<0,05$ sehingga dapat dinyatakan bahwa terdapat perbedaan hasil yang signifikan antara kelas eksperimen dengan kelas kontrol pada keterampilan proses sains kegiatan pengenalan gejala alam hujan.

Kata Kunci: keterampilan proses sains, metode pembelajaran eksperimen, gejala alam. 


\section{A. Pendahuluan}

Pendidikan pada anak usia dini bukan mengajar anak dapat membaca dan berhitung, tetapi diperlukan pembinaan yang memperhatikan seluruh aspek perkembangan serta memberikan rangsangan berupa kesempatan pada anak untuk menggunakan seluruh inderanya.

Pembelajaran sebaiknya memusatkan anak untuk dapat menjadi pembelajar yang aktif, anak-anak dibiasakan untuk mengenal dan mengejar berbagai unsur pengetahuan, keterampilan, dan kemampuan melalui berbagai pengamatan, penemuan, mencari, menemukan, mendiskusikan, menyimpulkan, dan pengungkapan berbagai hal yang terdapat di dalam lingkungan sekitar. Pembelajaran pada anak berdasarkan prinsip pembelajaran anak usia dini perlu diselenggarakan dengan konsep bermain, maka pembelajaran harus dilakukan dengan cara bermain.

Pembelajaran anak usia dini dilakukan dengan menggunakan permainan yang dapat meningkatkan seluruh aspek perkembangan anak terlebih pada aspek kognitif atau kemampuan dalam pemecahan suatu masalah. Anak bermain banyak hal salah satunya permainan sains, permainan sains pada anak-anak menawarkan kemungkinan untuk berekspresi, kreativitas, dan pemikiran penting.

Permainan sains pada anak merupakan suatu permainan yang proses nya sesuai dengan standar bermain anak. Permainan sains memiliki tujuan yang saman dengan tujuan kurikulum sekolah anak usia dini, yaitu untuk meningkatkan pikiran, hati dan tubuh anak secara keseluruhan atau untuk mengembangkan kecerdasan, emosi dan fisik jasmani serta kognitif, afektif dan psikomotorik anak. Maka, pendidikan sains memiliki dasar tujuan yaitu agar dapat menumbuhkembangkan individu-individu yang peduli terhadap lingkungan dan dapat memanfaatkan aspek-aspek dasar lingkungan untuk memecahkan masalah yang dihadapinya, Winarni, (2017 : 14).

Namun, tujuan tidak sebanding dengan realita berdasarkan hasil analisis deskriptif yang dilakukan oleh winarni terdapat 50\% guru mengalami kesulitan dalam mengajarkan sains pada anak dikarenakan keterbatasan waktu, masih terpacu pada lembar kerja siswa dan metode pembelajaran yang saangat berpusat pada anak.

Raudhatul Athfal (RA) Al Furqon pada kelompok B diperoleh data bahwa dari sejumlah 25 anak, 18 anak belum terlihat keterampilan proses sains karena proses pembelajaran sains masih terpaku pada lembar kerja siswa, sehingga diperlukan suatu upaya pembelajaran untuk dapat mengoptimalkannya.

Sehingga diperlukannya keterampilan proses sains anak. Keterampilan proses sains ialah memberikan kesempatan pada anak dalam memperoleh informasi baru melalui pengalaman secara nyata. Meliputi kemampuan dalam mengamati, membandingkan, mengklasifikasi atau mengelompokkan, mengukur dan mengkomunikasikan (Ayunda, 2020 : 3). Maka diperlukannya metode pembelajaran yang dapat meningkatkan keterampilan proses sains yaitu metode pembelajaran eksperimen. Metode pembelajaran eksperimen adalah cara untuk penyampaian materi pembelajaran, anak melakukan eksperimen melalui pengamatan, dengan membuktikan dan mengalami apa yang telah dipelajarinya. Hikam \& Nursari, (2020 :

Berdasarkan latar belakang yang telah diuraikan, perumusan masalah dalam penelitian ini ialah: "Apakah keterampilan proses sains anak di kelompok B RA Al Furqon Kabupaten Karawang dapat meningkat melalui metode pembelajaran eksperimen?".

Tujuan penelitian :

1. Gambaran keterampilan proses sains anak kelompok B kelas eksperimen dan kelas kontrol sebelum diterapkan metode pembelajaran eksperimen di RA Al Furqon Kabupaten Karawang

2. Menemukan hasil kemampuan proses sains anak kelompok B kelas eksperimen dan kelas kontrol di RA Al Furqon Kabupaten Karawang sesudah diterapkan metode pembelajaran eksperimen di RA Al Furqon Kabupaten Karawang

3. Menemukan hasil kemampuan proses sains anak kelompok B kelas eksperimen dan kelas kontrol di RA Al Furqon Kabupaten Karawang sesudah diterapkan metode pembelajaran eksperimen di RA Al Furqon Kabupaten Karawang 
120 | Kamila Mahabatillah.

\section{B. Metodologi Penelitian}

Penelitian menggunakan pendekatan kuantitatif, metode quasi eksperimen dengan desain nonequivalent control group design. Populasi penelitian ini 25 siswa kelompok B.

Pengambilan sampel yaitu teknik purpose sampling sebanyak 18 siswa. Teknik pengumpulan data yang digunakan adalah tes, wawancara, dan dokumentasi. Teknik analisis data dalam penelitian ini adalah Uji Normalitas, Uji Homogenitas Dan Uji Independent T Test

\section{Hasil Penelitian dan Pembahasan}

\section{Kemampuan Keterampilan Proses Sains Sebelum Diterapkan Metode Pembelajaran Eksperimen}

Dari Penelitian tes awal (pretest) yang dilakukan dengan metode tes dapat dihasilkan melalui tabel berikut :

Tabel 1. Data Pre Test Kemampuan keterampilan Proses Sains Anak

\begin{tabular}{|c|c|c|c|c|c|c|c|c|c|}
\hline \multirow{2}{*}{ No } & \multirow{2}{*}{$\begin{array}{l}\text { Nama } \\
\text { Siswa }\end{array}$} & \multicolumn{6}{|c|}{ Item Pengamatan } & \multirow{2}{*}{ Jumlah } & \multirow{2}{*}{$\begin{array}{r}\text { Rata } \\
\text { rata }\end{array}$} \\
\hline & & $\mathrm{A}$ & $\mathrm{B}$ & $\mathrm{C}$ & $\mathrm{D}$ & $\mathrm{E}$ & $\mathrm{F}$ & & \\
\hline 1 & DRD & 1 & 2 & 2 & 1 & 2 & 2 & 10 & 1.7 \\
\hline 2 & MPS & 2 & 2 & 3 & 1 & 1 & 1 & 10 & 1.7 \\
\hline 3 & APS & 2 & 1 & 3 & 1 & 3 & 1 & 11 & 1.8 \\
\hline 4 & AAA & 2 & 1 & 3 & 2 & 3 & 1 & 12 & 2.0 \\
\hline 5 & EZ & 2 & 3 & 1 & 2 & 3 & 2 & 13 & 2.2 \\
\hline 6 & AQA & 2 & 2 & 2 & 1 & 3 & 1 & 11 & 1.8 \\
\hline 7 & NPR & 2 & 3 & 3 & 2 & 2 & 2 & 14 & 2.3 \\
\hline 8 & NAS & 2 & 2 & 3 & 1 & 2 & 1 & 11 & 1.8 \\
\hline 9 & MFR & 2 & 1 & 2 & 2 & 3 & 1 & 11 & 1.8 \\
\hline 10 & AAB & 2 & 1 & 2 & 2 & 2 & 1 & 10 & 1.7 \\
\hline 11 & $\mathrm{EF}$ & 1 & 2 & 1 & 1 & 3 & 2 & 10 & 1.7 \\
\hline 12 & CAP & 1 & 2 & 3 & 1 & 2 & 2 & 11 & 1.8 \\
\hline 13 & $\mathrm{AKM}$ & 1 & 1 & 2 & 2 & 2 & 2 & 10 & 1.7 \\
\hline 14 & KIR & 2 & 2 & 2 & 2 & 1 & 1 & 10 & 1.7 \\
\hline 15 & MRR & 1 & 2 & 2 & 2 & 2 & 1 & 10 & 1.7 \\
\hline 16 & DAZ & 2 & 3 & 3 & 2 & 2 & 2 & 14 & 2.3 \\
\hline 17 & FUS & 2 & 3 & 1 & 2 & 2 & 2 & 12 & 2.0 \\
\hline 18 & EP & 2 & 2 & 2 & 2 & 2 & 2 & 12 & 2.0 \\
\hline & & $\mathrm{Ju}$ & ah & ata & & & & 202 & 11,2 \\
\hline
\end{tabular}

Keterangan Item :

A = Mengamati proses terjadinya hujan dengan 3 panca indra

$\mathrm{B}=$ Membandingkan perbedaan antara jenis hujan

$\mathrm{C}=$ Mengklasifikasikan awan

$\mathrm{D}=$ Mengukur banyak air hujan dari proses penguapan

$\mathrm{E}=$ Menunjukkan aktivitas eksploratif dan menyelidiki dampak terjadinya hujan

$\mathrm{F}=$ Mengenal sebab akibat terjadinya hujan

Berdasarkan tabel diatas menunjukan bahwa terdapat 18 siswa dengan nilai jumlah keterampilan proses sains 202 dan nilai rata-rata yaitu 11,2 Serta terdapat skor terendah dan skor tertinggi anak dapat dilihat pada tabel berikut : 
Tabel 2. Data Nilai Pre Test Keterampilan Proses Sains

\begin{tabular}{|l|c|}
\hline & Pretetst \\
\hline Nilai Terendah & 10 \\
\hline Nilai Tertinggi & 14 \\
\hline Rata-rata & 11,2 \\
\hline
\end{tabular}

\section{Hasil Keterampilan Proses Sains Anak}

Berdasarkan hasil penelitian dapat diperoleh hasil akhir melalui posttest penggunaan metode pembelajaran eksperimen melalui tabel berikut :

Tabel 3. Data Post Test Keterampilan Proses Sains

\begin{tabular}{|c|l|c|c|c|l|r|r|}
\hline \multicolumn{4}{|c|}{ Kelas Eksperimen } & \multicolumn{5}{c|}{ Kelas Kontrol } \\
\hline No & Nama & Jumlah & Rata-rata & No & Nama & Jumlah & Rata-rata \\
\hline 1 & DRD & 19 & 3.2 & 1 & ABR & 12 & 2.0 \\
\hline 2 & MPS & 19 & 3.2 & 2 & EF & 15 & 2.5 \\
\hline 3 & APS & 17 & 2.8 & 3 & CAP & 12 & 2.0 \\
\hline 4 & AAA & 22 & 3.7 & 4 & AKM & 14 & 2.3 \\
\hline 5 & EZ & 22 & 3.7 & 5 & KIR & 14 & 2.3 \\
\hline 6 & AQA & 20 & 3.3 & 6 & MRR & 15 & 2.5 \\
\hline 7 & NPR & 19 & 3.2 & 7 & DAZ & 14 & 2.3 \\
\hline 8 & NAS & 19 & 3.2 & 8 & FUS & 19 & 3.2 \\
\hline 9 & MFR & 15 & 2.5 & 9 & EP & 18 & 3.0 \\
\hline Jumlah/rata-rata & 172 & 19.1 & \multicolumn{2}{|c|}{ Jumlah/rata-rata } & 133 & 14.8 \\
\hline
\end{tabular}

Berdasarkan tabel diatas menunjukan bahwa terdapat 8 siswa dari kelas eksperimen dan 8 siswa dari kelas kontrol. Nilai rata-rata data keterampilan proses sains saat posttest untuk kelompok eksperimen sebesar 19.1. Sedangkan kelas kontrol memiliki nilai rata-rata 14.8 Serta terdapat skor terendah dan skor tertinggi anak dapat dilihat pada tabel berikut :

Tabel 4. Data Nilai Post Test Keterampilan Proses Sains

\begin{tabular}{|l|c|c|}
\hline & $\begin{array}{c}\text { Posttest Kelas } \\
\text { Eksperimen }\end{array}$ & $\begin{array}{c}\text { Posttest Kelas } \\
\text { Kontrol }\end{array}$ \\
\hline Nilai Terendah & 15 & 12 \\
\hline Nilai Tertinggi & 22 & 19 \\
\hline Rata-rata & 19,1 & 14,8 \\
\hline
\end{tabular}

Dari tabel diatas dapat diketahui jika hasil posttest kelas eksperimen pada penilaian nilai terendah 15, nilai tertinggi 22, dengan rata-rata sebesar 19.1. Sedangkan nilai posttest kelas kontrol nilai terendah 12, nilai tertinggi 19 dan rata-rata sebesar 14.8

Meningkatan Keterampilan Proses Sains (X) Melalui Metode Pembelajaran Eksperimen (Y)

Berikut adalah penelitian mengenai meningkatkan keterampilan proses sains memalui metode pembelajaran eksperimen, yang diuji menggunakan Uji Independent $T$ Test. Sebelum diterampkan Uji Indepent T Test dilakukan Uji Normalitas Dan Homogenitas. Uji Normalitas dilakukan menggunakan kolmogorov-smirnov dengan taraf signifikan 0,05. 
Tabel 5. Uji Normalitas

\begin{tabular}{|l|l|r|r|r|r|r|r|}
\hline \multicolumn{2}{|c|}{ Tests of Normality } \\
\hline \multirow{2}{*}{} & Kelas & \multicolumn{2}{|c|}{ Kolmogorov-Smirnov } & \multicolumn{3}{|c|}{ Shapiro-Wilk } \\
\cline { 3 - 9 } & & \multicolumn{1}{c|}{ Statistic } & \multicolumn{1}{c|}{ df } & \multicolumn{1}{c|}{ Sig. } & \multicolumn{1}{c|}{ Statistic } & df & \multicolumn{1}{c|}{ Sig. } \\
\hline \multirow{3}{*}{ Hasil Keterampilan Proses Test Eksperimen } & .297 & 9 & .021 & .874 & 9 & .136 \\
Sains & Post Test Eksperimen & .258 & 9 & .087 & .907 & 9 & .298 \\
& Pre Test Kontrol & .316 & 9 & .010 & .763 & 9 & .008 \\
& Post Test Kontrol & .241 & 9 & .141 & .888 & 9 & .189 \\
\hline
\end{tabular}

a. Lilliefors Significance Correction

Berdasarkan hasil uji normalitas nilai pre test dan post test dari kedua kelas berdistribusi normal. Karena pre test kelas eksperimen diperoleh nilai signifikasi 0,021 , pre test kelas kontrol 0,10 , post test kelas eksperimen 0,87 , dan post test kelas kontrol 0,141 , seluruh signifikasi diatas taraf signifikan 0,05. Uji Homogenitas dilakukan terhadap hasil nilai post test kelas eksperimen dan kelas kontrol. Uji Homogenitas dilakukan dengan menggunakan levene mendapatkan hasil perhitungan sebagai berikut :

Tabel 6. Hasil Uji Homogenitas

\begin{tabular}{|c|c|c|c|}
\hline Levene Statistic & df1 & $\mathrm{df} 2$ & Sig. \\
\hline 143 & 1 & 16 & .710 \\
\hline
\end{tabular}

ANOVA

Hasil Keterampilan Proses Sains
\begin{tabular}{|l|r|r|r|c|c|}
\hline & Sum of Squares & df & Mean Square & F & Sig. \\
\hline Between Groups & 84.500 & 1 & 84.500 & 16.011 & .001 \\
Within Groups & 84.444 & 16 & 5.278 & & \\
Total & 168.944 & 17 & & & \\
\hline
\end{tabular}

Hasil uji homogenitas nilai post test kelas eksperimen dan kelas kontrol diperoleh signifikasi 0,710. Maka dapat disimpulkan bahawa nilai sig $>0,05$ artinya kelas eksperimen dan kelas kontrol bersifat homogen. Analisis data yang digunakan dalam penelitian ini menggunakan rumus Uji Independent T Test dengan taraf signifikan 0,05, untuk pengujian hipotesis.

Tabel 7. Hasil Uji Hipotesis

\begin{tabular}{|l|l|c|c|}
\hline \multicolumn{1}{|c|}{ Data } & Rata-rata & Selisih & sig. (2-talled) \\
\hline Posttest kelas eksperimen & 19,1 & \multirow{2}{*}{4,3} & 0,001 \\
\cline { 1 - 1 } \cline { 4 - 5 } & 14,8 & & 0,001 \\
\hline
\end{tabular}

Berdasarkan tabel di atas terdapat selisih 4,3 antara kelas eksperimen dengan kelas kontrol pada kelas eksperimen memperoleh nilai rata-rata nilai sebesar 19,1 lebih besar dari rata-rata kelas kontrol sebesar 14,8. Pada hasil Uji Independent T Test diperoleh nilai sig. (2talled) sebesar $0,001<0,05$, maka $\mathrm{H}_{\mathrm{a}}$ diterima dan $\mathrm{H}_{\mathrm{o}}$ ditolak. Dengan demikian terdapat perbedaan hasil yang signifikan antara kelas eksperimen dengan kelas kontrol pada keterampilan proses sains kegiatan pengenalan gejala alam hujan. Sehingga metode pembelajaran eksperimen dapat meningkatkan keterampilan proses sains.

\section{Kesimpulan}

Berdasarkan pembahan pada penelitian ini, peneliti menyimpulkan beberapa hasil penelitian 
diantaranya :

Sebelum diterapkan metode pembelajaran eksperimen kemampuan keterampilan proses sains anak belum terlihat hal ini ditinjau berdasarkan hasil observasi awal anak belum tertarik untuk mengikuti pembelajaran dimana kelas eksperimen sebelum diterapkan metode pembelajaran eksperimen memperoleh nilai rata-rata 11,4 dan kelas kontrol 11,0. Penilaian akhir post test kelas eksperimen dengan kelas kontrol kelas eksperimen mendapatkan post test 19.1 sedangkan kelas kontol memperoleh nilai post test 14.8.

Setelah dilakukannya penilaian keterampilan proses sains anak awal dan akhir, maka dilakukan analisis data untuk melihat pengaruh dan efektifitas metode pembelajaran eksperimen dalam meningkatkan keterampilan proses sains anak. Hasil analisis data melalui hipotesis sebesar $0,001<0,05$, maka $\mathrm{H}_{\mathrm{a}}$ diterima $\mathrm{H}_{\mathrm{o}}$ ditolak. Maka hasil keterampilan proses sains anak meningkat dengan diberikan perlakuan metode pembelajaran eksperimen dibandingkan tidak mendapatkan perlakukan metode pembelajaran eksperimen. Peningkatan keterampilan proses sains melalui metode pembelajaran eksperimen karea anak mengalaminya dan membuktikannya sendiri

\section{Acknowledge}

Proses penyusunan penelitian ini tidak dapat luput dari berbagai macam kendala. Namun, dukungan yang selalu diberikan oleh orang-orang disekitar peneliti yang memberikan semangat dan motivasi yang begitu besar.

\section{Daftar Pustaka}

[1] Winarni, D. S. (2017). Analisis Kesulitan Guru PAUD dalam Membelajarakan IPA pada Anak Usia Dini. Edu Sains: Jurnal Pendidikan Sains \& Matematika, 5(1), 12. https://doi.org/10.23971/eds.v5i1.578

[2] Ayunda, S. R. A. I. S. (2020). Pembelajaran Sains dan Matematika Anak Usia Dini (1st ed.). Caremedia Communication. https://books.google.co.id/

[3] Hikam, F. F., \& Nursari, E. (2020). Analisis Penggunaan Metode Eksperimen Pada Pembelajaran Sains Bagi Anak Usia Dini. 2, 38-49. 